\title{
Ujjon lévő cystosus elváltozás hátterében diagnosztizált dirofilariosis
}

\author{
Molnár Klára dr. ${ }^{1}$ - Józsa Gergő dr. ${ }^{2}$ - Oberritter Zsolt dr. ${ }^{2}$ \\ Cholnoky Eszter dr. ${ }^{3}$. Pankovics Péter dr. ${ }^{4}$. Reuter Gábor dr. ${ }^{4}$ \\ Tornóczky Erika dr. ${ }^{4}$
}

${ }^{1}$ Fejér Megyei Szent György Egyetemi Oktató Kórház, Székesfehérvár Pécsi Tudományegyetem, Gyermekklinika, ${ }^{2}$ Gyermeksebészeti Osztály, ${ }^{3}$ Radiológiai Osztály, Pécs ${ }^{4}$ Baranya Megyei Kormányhivatal Népegészségügyi Szakigazgatási Szerve, Laboratóriumi Osztály, Parazitológiai Laboratórium, Pécs

\begin{abstract}
A dirofilariosis egy fonalféreg által okozott fertőzo betegség. A humán fertőzésekért leggyakrabban a Dirofilaria repens a felelős. A fonalféreg kutyáról, ritkábban macskáról, szúnyog közvetítésével terjed át az emberre, és a parazita által okozott helyi gyulladás miatt csomó alakulhat ki. A szerzők 13 éves fiúgyermek jobb kéz középső ujján kialakult ciszta hátterében diagnosztizált dirofilariosis esetét mutatják be. A gyermeknél a fizikális vizsgálat során a jobb kéz középső ujj középpercén a feszítőfelszínen elhelyezkedő subcutan csomót észleltek. Lágyrész-ultrahangvizsgálat a cisztikus elváltozásban féreg jelenlétét vetette fel. A ciszta helyi érzéstelenítésben történő eltávolítását követően a parazitológiai vizsgálat a Dirofilaria repens fonalféreg általi fertőzést igazolt. A gyermek a ciszta eltávolítását követően panasz- és szövődménymentesen gyógyult. A kéz ujjain megjelenő szoliter elváltozás sokszor jelent differenciáldiagnosztikai problémát. A preoperatív diagnózis felállításában nagy segítséget nyújthat az ultrahangvizsgálat. A szerzők felhívják a figyelmet, hogy a jelentett humán dirofilariás esetek száma az elmúlt években hazánkban emelkedik. Orv. Hetil., 2016, 157(39), 1571-1574.
\end{abstract}

Kulcsszavak: kéz, ujj, ciszta, gyermek, humán dirofilaria

\begin{abstract}
An unusual cause of the hand cyst: finger dirofilariasis
Dirofilariasis is a zoonosis affecting dogs and cats. It can be transmitted to human by mosquito bites. Because of the local inflammation caused by the parasite, a lump may develop. The authors present a case of a 13 -year-old boy, who was diagnosed with dirofilariasis in association with a cyst located on the middle finger of the right hand. During physical examination, a lump on the extensor surface of the middle phalanx of the right middle finger was found. Soft tissue ultrasound was performed, which indicated the presence of a worm in the cyst. The cyst was surgically removed under local anesthesia and with parasitology test Dirofilaria repens infection was confirmed. The child had no complains or symptoms during recovery after the surgery. A solitary growth developing on the fingers of the hand often presents a differential diagnostic problem. Ultrasound can be greatly helpful in the preoperative diagnosis.
\end{abstract}

Keywords: hand, finger, cyst, childhood, human dirofilariasis

Molnár, K., Józsa, G., Oberritter, Zs., Cholnoky, E., Pankovics, P., Reuter, G., Tornóczky, E. [An unusual cause of the hand cyst: finger dirofilariasis]. Orv. Hetil., 2016, 157(39), 1571-1574.

(Beérkezett: 2016. július 6.; elfogadva: 2016. július 22.)

Az emberi subcutan dirofilariosis ritka fertőző betegség, amelyet a Dirofilaria nemzetségbe tartozó fonalférgek okoznak. A nemzetségbe tartozó fonalférgeknek több faja ismert. Európában az emberi subcutan fertőzések döntő többségét a Dirofilaria repens okozza [1]. A fer- tőzés általában kutya által, ritkábban macska vagy szúnyog (Culex, Aedes fajok) közvetítésével terjed át az emberre. A féreg a hordozó állatokban bőr-, szív- és vascularis megbetegedést okozhat, míg emberben inkább bör- vagy szemdirofilariosist [2]. A Dirofilaria repens 
fejlődési ciklusában az ember végső gazda lehet. A microfilaria a behatolás helyétől kisebb-nagyobb távolságokat képes megtenni az emberben, leggyakrabban az eredeti behatolás közelében okoz a subcutan rétegben cystosus térfoglalást, úgynevezett csomót, amiben a faj egy, többnyire nem ivarérett példánya található meg. A klinikai tüneteket a laza bőr alatti szövetekben elhelyezkedő féreg okozta helyi elváltozások adják. A csomók bárhol előfordulhatnak a bőrben, de leggyakrabban a test felső részére (fej, szem, nyak, felső végtagok, mellkas) lokalizálódnak $[3,4]$. Míg a test különböző részein kialakuló bőr alatti csomó sokáig észrevétlen maradhat, addig a szem körüli, elsősorban a kötőhártya alatti elváltozások korán feltünést keltenek [5]. A fájdalom és egyéb gyulladásos tünetek miatt a beteg korán kerül orvoshoz. A kifejlődött férgek a vénás keringéssel más szervekbe is vándorolhatnak [6], ritkán más régiókban, például a tüdőben, a csepleszben is megjelenhetnek $[6,7]$. A féreg vagy a férget tartalmazó csomó sebészi kimetszése végleges gyógyulást eredményezhet. Gyógyszeres (parazitaellenes) kezelés nem szükséges [1].

A bőr alatt élősködő Dirofilaria repens elsődleges hordozója a kutya, ritkábban a macska. A Dirofilaria repens megjelenését tekintve a kifejlett nőstény 10-17 cm, míg a hím 5-7 cm hosszú, átmérőjúk pedig 0,5 mm. A Dirofilaria repens kutikulája redős mintázatot mutat, a feji végén, a szájnyílásnál kis behúzódás látható, míg a farki vég egyenes és vékony.

Az Országos Epidemiológiai Központ Parazitológiai Osztályán 2001 és 2013 között 88 esetet diagnosztizáltak, amelyek közül 34 a szemet érintette, 53 esetben bőr alatti csomóból, 1 esetben az eltávolított nyirokcsomóból mutatták ki a férget [8].

\section{Esetismertetés}

A 13 éves fiúgyermek jobb kéz középső ujj középpercének feszítőfelszínén lévő csomó miatt jelentkezett 2015 nyarán a Pécsi Gyermekklinika gyermeksebészeti szakrendelésén.

Az édesanya a gyermek jobb kéz középső ujján a megjelenést megelőzően 1 hónappal korábban észlelte a körülbelül $1 \mathrm{~cm}$ átmérőjű duzzanatot. A gyermek az elmúlt egy évben külföldön nem tartózkodott. Az elsődleges vizsgálat során $15 \times 6 \mathrm{~mm}$-es, fájdalmatlan, mobilis terimét tapintottunk a jobb kéz középső ujj középpercének dorsoradialis felszínén. Az elváltozás az ujjon funkciókiesést, érzés- vagy keringészavart nem okozott. A lágyrész-ultrahangvizsgálat $17 \times 5 \mathrm{~mm}$-es, jól körülhatárolt, fallal bíró, folyadékot és keskeny, tubularis echókat tartalmazó kerekded képletet írt le. Az apró tubularis képletek finom mozgását észleltük a vizsgálat során, ennek alapján merült fel a ciszta parazitás eredete.

Vezetéses érzéstelenítésben a ciszta egészben eltávolításra került, majd a ciszta megnyitása után egy mozgó féreg jelent meg, amely idegentest-reakciót okozott a lágy részekben (1. és 2. ábra). A Baranya Megyei Kor- mányhivatal Népegészségügyi Szakigazgatási Szervének Laboratóriumi Osztálya Parazitológiai Laboratóriumával történt konzultáció felvetette dirofilariosis lehetőségét. A sebészeti beavatkozást követően 1 órával a laboratóriumba küldött férget tartalmazó cisztában a fonalféreg még mozgott. Makroszkóposan a fonalféreg fehér színü, $15 \mathrm{~cm}$ hosszú és $1 \mathrm{~mm}$ átmérőjü volt. A natív fénymikroszkópos vizsgálattal láthatóak voltak a fonalféreg testén és a feji részén a kutikularedők (3. ábra). Ezek alapján egy nőstény Dirofilaria repens fonalféreg jelenléte igazolódott. Feltehetően a szúnyogcsípés helyén kialakult subcutan szöveti cisztában a harmadik stádiumú (fertőző) lárva felnőtt nőstény egyeddé fejlődött ki. Az izoláltan kifejlödött fonalféreg steril is maradt, mivel a cisztában egyéb microfilarialárvát natív mikroszkópos vizsgálattal nem tudtunk kimutatni. Egy héttel a mütétet követően a gyermek panasz- és szövődménymentesen gyógyult. Parazitaellenes kezelésre nem volt szükség.

\section{Megbeszélés}

A humán subcutan dirofilariosis ritka fertőző megbetegedés, zoonosis, amelyet a Dirofilaria nemzetségbe tartozó fonalféreg, a Dirofilaria repens okoz. Európa északkeleti területeire, így hazánkba is, az esetek nagy részében külföldről kerül be. Azonban a microfilarialárvákat is hordozó szúnyogfajok (Culex és Aedes szúnyogfajok) élettere a globális felmelegedés és fokozott csapadékos időjárás hatására fokozatosan északabbra tolódik, így a dokumentált esetek száma az utóbbi évtizedben növekedést mutat, nemcsak a mediterrán országokban, hanem Magyarországon is $[9,10]$. Ma már bizonyított tény, hogy a Dirofilaria repens hazai elöfordulása kutyákban nem ritka, enyhe bőrgyulladással, viszketéssel és szőrhullással járó megbetegedést és súlyos cardiovascularis dirofilariosist okoz.

A környezeti változások, a globális felmelegedés is kedvez a szúnyogok elszaporodásának. A kutyás turizmus, kutyakiállítások, vendégvadászok és kutyáiknak rendszeres látogatása a behurcolt esetek számát növeli.

A humán fertőzések többnyire tünetmentesek. A subcutisban fejlődő gócok leggyakoribb előfordulási helyei a mell és végtagok. Esetünkben a kéz középső ujj középpercének dorsoradialis felszínén diagnosztizáltunk egy fejlődő gócot. A kéz ujjain megjelenő szoliter elváltozás sokszor jelent differenciáldiagnosztikai problémát. Subcutan csomók, cystosus elváltozások esetén gondolhatunk ganglionra, idegen test okozta granulomára, lágyrész-daganatra és tályogra is. A preoperatív diagnózis felállításában, ahogy az általunk bemutatott esetben is, nagy segítséget nyújthat az ultrahangvizsgálat. A féreg vagy a férget tartalmazó csomó sebészi kimetszése végleges gyógyulást eredményezhet. Gyógyszeres (parazitaellenes) kezelés nem szükséges [1].

A laboratóriumi vizsgálatok során a vérben előforduló különböző dirofilarialárvák elkülönítése festett kenet vizsgálatával nem, csak molekuláris biológiai módszerrel 


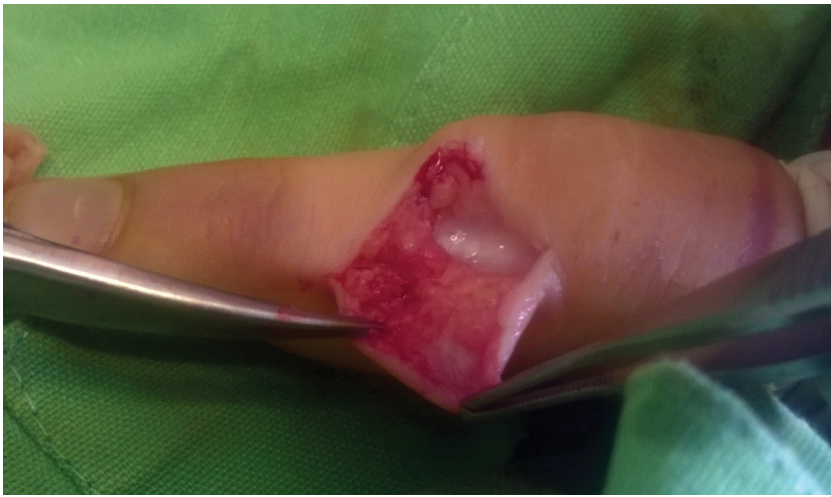

1. ábra ín

lehetséges. A felnőtt fonalférgek viszont már jellegzetes morfológiai bélyegekkel rendelkeznek, így makroszkópos és natív mikroszkópos vizsgálatokkal a faj kifejlett példánya könnyen besorolható.

Igen fontos hangsúlyozni a megelőzést, amelynek az egyik legfontosabb eleme a kutyák állatorvos által vég-

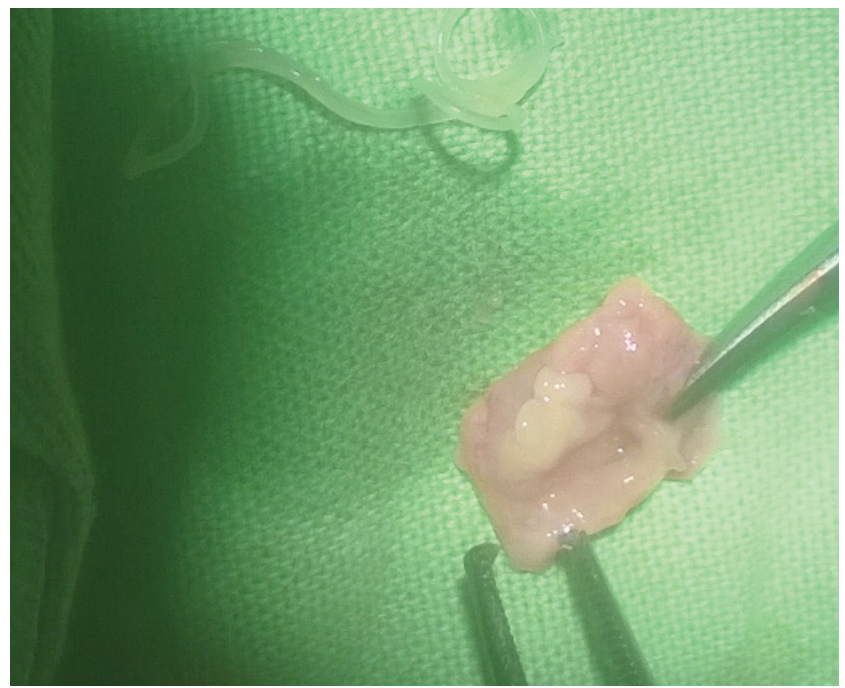

2. ábra A megnyitott ciszta és az abból származó fonalféreg (Dirofilaria repens)

zett szűrővizsgálata, az állatok megelőző gyógyszeres kezelése és a fertőzött kutyák kezelése. Megelőzhető továbbá a dirofilariosis szúnyogok irtásával, szúnyogcsípés
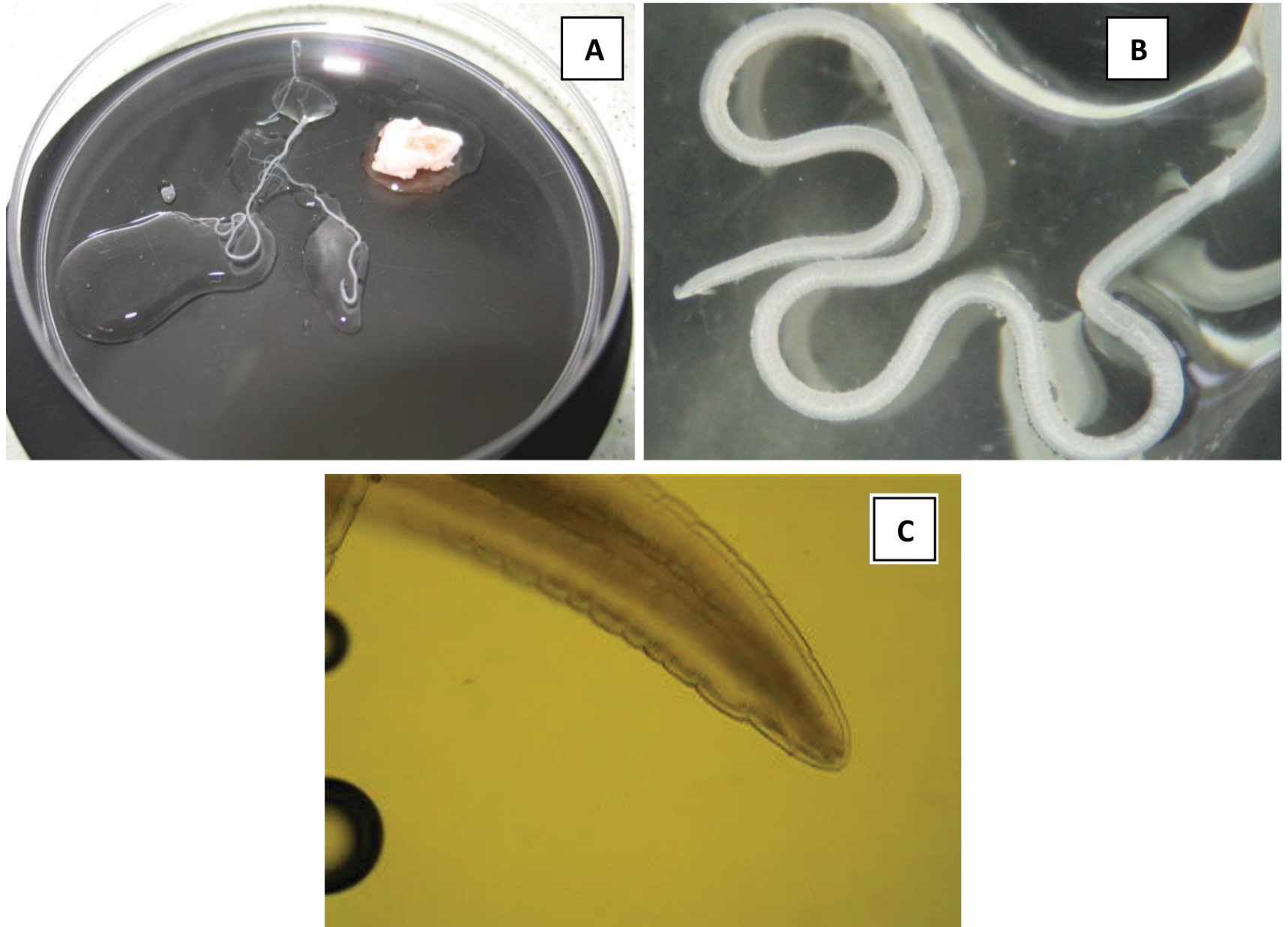

3. ábra

A Dirofilaria repens telepmikroszkópos $(10 \times)(\mathrm{A}, \mathrm{B})$ és natív fénymikroszkópos $(250 \times)(\mathrm{C})$ felvétele. A laboratóriumi vizsgálat alatt még élő felnőtt fonalférget a laboratóriumba küldött cisztában találtuk (A). A feltárás során a féreg kettészakadt, hossza $15 \mathrm{~cm}$ volt. A fehér színú féreg cutisa bordázott felszíni struktúrát mutatott $(\mathrm{B})$, amely tisztán látható volt a feji részen $(\mathrm{C})$ 
elleni védekezéssel. Növeli a fertőzés kockázatát a víz közeli lakóhely vagy tartózkodás a közti gazdaként szereplő szúnyogpopuláció nagy sürüsége miatt.

Fájdalmatlan, növekvő subcutan csomó esetén és szúnyogcsípés anamnézise mellett differenciáldiagnosztikai szempontból már hazánkban is fel kell merüljön a dirofilariosis lehetősége.

Anyagi támogatás: A közlemény megírása anyagi támogatásban nem részesült.

Szerzői munkamegosztás: M. K.: A kézirat megírása. O. Zs: A kézirat megírása és a dolgozat javítása, ellenőrzése. C. E., J. G.: A hipotézis kidolgozása. P. P., R. G., T. E.: A telemikroszkópos képanyag és a szöveg szerkesztése. A cikk végleges változatát valamennyi szerző elolvasta és jóváhagyta.

Érdekeltségek: A szerzőknek nincsenek érdekeltségeik.

\section{Irodalom}

[1] Szénási, Z., Kovács, A. H., Pampiglione, S., et al.: Human dirofilariosis in Hungary: an emerging zoonosis in central Europe. Wien. Klin. Wochenschr., 2008, 120(3), 96-102.
[2] Fok, É., Varga, Zs.: Clinical helminthology. [Klinikai helmintológia.] Porta-Vet Kiadó, Budapest, 2006. [Hungarian]

[3] Otranto, D., Diniz, D. G., Dantas-Torres, T., et al.: Human intraocular filariasis caused by Dirofilaria sp. nematode, Brazil. Emerg. Infect. Dis., 2011, 17(5), 863-866.

[4] Conly, J. M., Sekla, L. H., Low, D. E.: Dirofilariasis presenting as a breast lump. Can. Med. Assoc. J., 1984, 130(12), 1575-1576.

[5] Joseph, E., Matthai, A., Abraham, L. K., et al.: Subcutaneous human dirofilariasis. J. Parasit. Dis., 2011, 35(2), 140-143.

[6] Radovanović Spurnić, A. P., Stevanović, G., Dakic, Z., et al.: Human subcutaenous dirofilariasis - case report. Med. Pregl., 2015, 68(7-8), 273-276.

[7] Glavan, N., Pećanić, S., Bosak, A., et al.: Dirofilaria repens infection in a ten-year-old boy from the Istria Peninsula: case report. Acta Clin. Croat., 2013, 52, 533-536.

[8] Kucsera, I., Danka, J., Orosz, E.: Human dirofilariasis in Hungary. [Humán dirofilariosis Magyarországon.] Epinfo, 2014, 21(24), 273-277. [Hungarian]

[9] Kramer, L. H., Kartashev, V. V., Grandi, G., et al.: Human subcutaneous dirofilariasis, Russia. Emerg. Infect. Dis., 2007, 13(1), $150-152$.

[10] Ondriska, F., Lengyel, D., Miterpakova, M., et al.: Human dirofilariasis in the Slovak republic - a case report. Ann. Agric. Environ. Med., 2010, 17(1), 169-171.

(Józsa Gergő dr., Pécs, József A. u. 7., 7623 e-mail: dr.jozsa.gergo@gmail.com)

\section{A rendezvények és kongresszusok híranyagának leadása}

a lap megjelenése előtt legalább 40 nappal lehetséges, a 6 hetes nyomdai átfutás miatt. Kérjük megrendelőink szíves megértését.

A híranyagokat a következő címre kérjük: Orvosi Hetilap titkársága: Budai.Edit@akkrt.hu Akadémiai Kiadó Zrt. 